\title{
Transforming Growth Factor-Beta Family Gene
}

National Cancer Institute

\section{Source}

National Cancer Institute. Transforming Growth Factor-Beta Family Gene. NCI

Thesaurus. Code C21345.

Expressed in a variety of tissues, Transforming Growth Factor-Beta Family Genes encode Transforming Growth Factor-Beta, an autocrine growth factor that can act synergistically with T GF-alpha in embryonic development, cellular differentiation, hormone secretion, and immune function. There are at least three forms of T GF-beta: T GF-beta 1, T GF-beta 2, and T GF-beta 1.2. The latter is a heterodimer of T GF-beta 1 and TGF-beta 2. (NCl) 